\title{
Sources of short-lived bromocarbons in the Iberian upwelling system
}

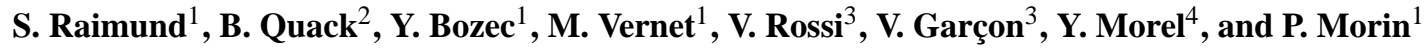 \\ ${ }^{1}$ CNRS-UPMC Univ Paris 06, UMR 7144, Adaptation et Diversité en Milieu Marin, Equipe Chimie Marine, Station \\ Biologique de Roscoff, 29682 Roscoff, France \\ ${ }^{2}$ Department of Marine Biogeochemistry, Leibniz-Institute of Marine Science, Kiel, Germany \\ ${ }^{3}$ Laboratoire d'Etudes en Geophysique et Oceanographie Spatiales, CNRS, Toulouse, France \\ ${ }^{4}$ Service Hydrographique et Océanographique de la Marine, (SHOM), Toulouse, France
}

Received: 5 November 2010 - Published in Biogeosciences Discuss.: 30 November 2010

Revised: 22 May 2011 - Accepted: 23 May 2011 - Published: 17 June 2011

\begin{abstract}
Seawater concentrations of the four brominated trace gases, dibromomethane $\left(\mathrm{CH}_{2} \mathrm{Br}_{2}\right)$, bromodichloromethane $\left(\mathrm{CHBrCl}_{2}\right)$, dibromochloromethane $\left(\mathrm{CHBr}_{2} \mathrm{Cl}\right)$ and bromoform $\left(\mathrm{CHBr}_{3}\right)$ were measured at different depths of the water column in the Iberian upwelling off Portugal during summer 2007. Statistical analysis of the data set revealed three distinct clusters, caused by different sea surface temperature. Bromocarbon concentrations were elevated in recently upwelled and aged upwelled waters (mean values of $30 \mathrm{pmoll}^{-1}$ for $\mathrm{CHBr}_{3}$ ), while concentrations in the open ocean were significantly lower (7.4 $\mathrm{pmol}^{-1}$ for $\mathrm{CHBr}_{3}$ ). Comparison with other productive marine areas revealed that the Iberian upwelling had higher halocarbon concentrations than the Mauritanian upwelling. However, the concentrations off the Iberian Peninsula were still much lower than those of coastal macroalgal-influenced waters or those of Polar regions dominated by cold water adapted diatoms. Correlations with biological variables and marker pigments indicated that phytoplankton was a source of bromocarbon in the open ocean. By contrast, in upwelled water masses along the coast, halocarbons showed weaker correlations to marker pigments but were significantly influenced by the tidal frequency. Our results indicate a strong intertidal coastal source of bromocarbon and transport by surface currents of these enriched waters towards the upwelling region.
\end{abstract}

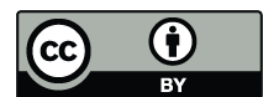

Correspondence to: S. Raimund (raimund@sb-roscoff.fr)

\section{Introduction}

Oceans are a source of short-lived bromocarbons such as dibromomethane $\left(\mathrm{CH}_{2} \mathrm{Br}_{2}\right)$, bromodichloromethane $\left(\mathrm{CHBrCl}_{2}\right)$, dibromochloromethane $\left(\mathrm{CHBr}_{2} \mathrm{Cl}\right)$ and bromoform $\left(\mathrm{CHBr}_{3}\right)$ via exchange processes from the ocean surface layer to the atmosphere. Photo-oxidative breakdown of bromocarbons elevates atmospheric bromine concentrations and affects both tropospheric and stratospheric chemistry and has implications for climate (Law and Sturges, 2006). In the troposphere, bromine influences the $\mathrm{NO} / \mathrm{NO}_{2}$ cycle, stimulates catalytic ozone depletion cycles and influences the life times of other trace gases (Read et al., 2008; von Glasow et al., 2004). Rapid deep convection can transport bromocarbons to the lower stratosphere where they may represent $20-60 \%$ of stratospheric bromine and consequently contribute to ozone depletion (Salawitch et al., 2005). Macroalgae and phytoplankton are the main sources for oceanic bromocarbons (Manley et al., 1992; Moore et al., 1996; Carpenter and Liss, 2000; Butler et al., 2007) and algal species composition and productivity influence spatial and temporal distribution of halocarbons on a global scale (Carpenter et al., 2005). Catalysis by haloperoxidases (Leblanc et al., 2006), enzymes found in both macroalgae and phytoplankton, is an important biological production pathway of polyhalogenated alkanes, but the biological function of these reactions still remains unclear. Besides natural sources, anthropogenic discharge represents a significant additional halocarbon source in some coastal areas (Quack and Wallace, 2003). Haloperoxidase-containing phytoplankton species have been held responsible for elevated halocarbon concentrations in both laboratory experiments (Moore et al., 1996) and

Published by Copernicus Publications on behalf of the European Geosciences Union. 

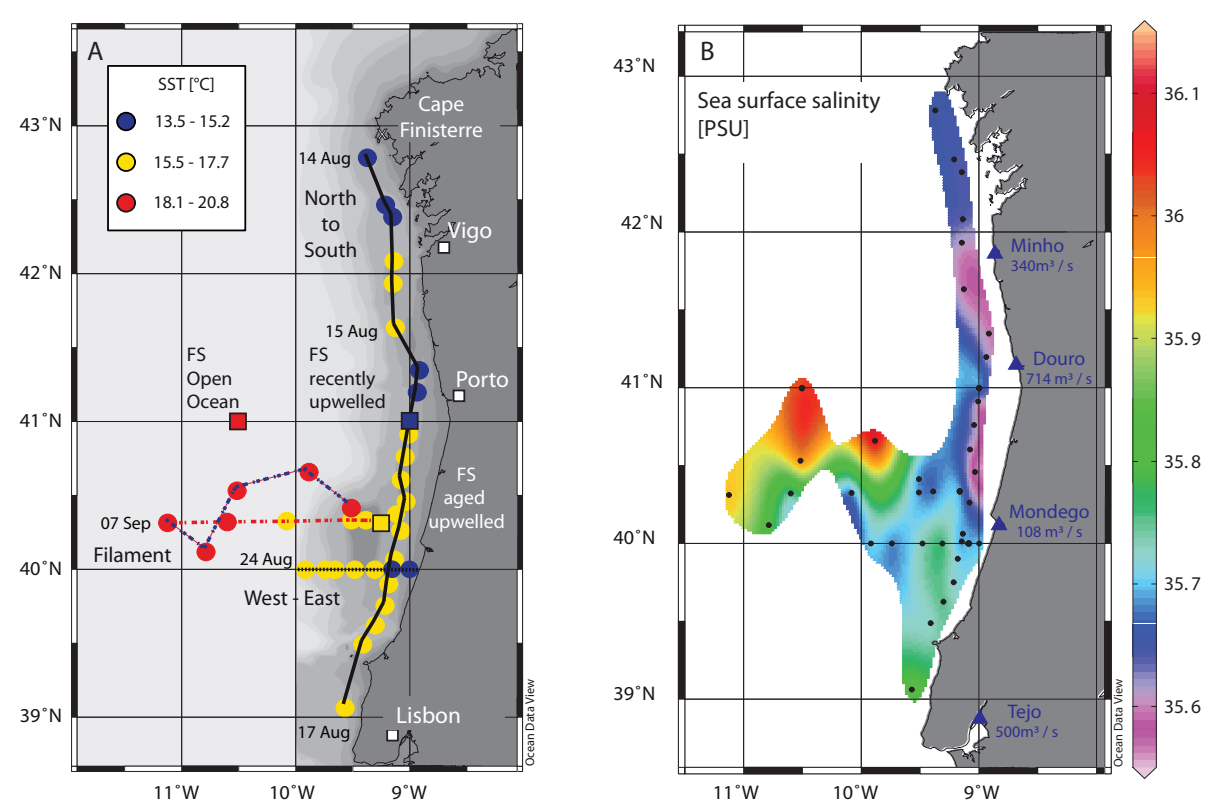

Fig. 1. (A) Cruise track of the Mouton campaign 2007 in the Iberian peninsula upwelling system. Samples were taken at different CTD stations (marked as dots) and along three different tracks (marked as lines). The solid line represents the north to south track within the upwelling. The dotted black line marks the west to east track which followed $40^{\circ} \mathrm{N}$ from the open ocean toward the upwelling. Dashed red and blue lines show a track following a filament. Fixed stations (FS, marked as squares) were sampled over $30 \mathrm{~h}$ periods. Colours represent station clustering by sea surface temperature (SST). Date specifications are given for selected stations. (B) Sea surface salinity. River mouths of the most important rivers in the sampling area (blue triangles), with average discharge.

field campaigns (Hughes et al., 2009). Although aqueous bromocarbons have been investigated in a wide range of marine regions, few studies have focused on the highly productive, phytoplankton-dominated upwelling regions, which have nevertheless been assumed to be important sources for global bromocarbon production. In this study we present seawater concentrations of $\mathrm{CH}_{2} \mathrm{Br}_{2}, \mathrm{CHBrCl}_{2}$, $\mathrm{CHBr}_{2} \mathrm{Cl}$ and $\mathrm{CHBr}_{3}$ measured during late summer 2007 along the coast off Portugal and discuss different possible sources for these trace gases.

\section{Methods}

\subsection{Sampling and study area}

During summer 2007 (11 August to 14 September), we investigated halocarbon distributions in the Iberian peninsula upwelling system along the coast off Portugal onboard the French research vessel Pourquoi pas during the MOUTON (Modélisation océanique d'un théâtre d'opérations navales) campaign. Samples were taken at 69 CTD stations along three different transects. Additional samples were taken during daily cycles at fixed stations (Fig. 1) with a 12-bottle CTD rosette (10-L-Niskin bottles). At each station, up to five samples were collected in the water column: surface layer, upper thermocline layer, chlorophyll maximum layer, lower thermocline layer and bottom depth. Samples were taken to determine bromocarbon concentrations, pigment composition and nutrient concentrations. Meteorological conditions and bio-physical data from this cruise are discussed in detail by Rossi et al. (2011).

The study area extended from $39.1^{\circ} \mathrm{N}$ to $42.8^{\circ} \mathrm{N}$ and $8.9^{\circ} \mathrm{W}$ to $11.1^{\circ} \mathrm{W}$ within the Iberian peninsula upwelling system, which is the northern extent of the wind-driven Canaries eastern boundary upwelling system. The Iberian peninsula upwelling system ranges from about $36^{\circ} \mathrm{N}$ to about $46^{\circ} \mathrm{N}$ and from the Iberian coast to approximately $24^{\circ} \mathrm{W}$ (Perez et al., 2001). During summer north/northwesterly trade winds create a southward flow, which generates an offshore Ekman transport that is responsible for the upwelling of cold and nutrient enriched waters from 100-300 m depth to the surface along the coastline (Smyth et al., 2001). Upwelling events are usually strongest in the north of the Iberian peninsula upwelling system (off Cap Finisterre) and are often related to westward flowing advection. These so-called filaments are bands of cold and fresher waters, which can reach as far as $100 \mathrm{~km}$ westward (Coelho et al., 2002).

\subsection{Environmental variables}

Environmental variables were recorded in the water column by a CTD rosette and simultaneously in the air by the meteorological sensors of the vessel. Oxygen values 
were calibrated by independent sampling from discrete samples analyzed by Winkler titration with an accuracy of $\pm 1 \mu \mathrm{M}$. Pigments were analysed with the HPLC technique described by Wright et al. (1991), using a HPLC system (THERMO spectrasystem) equipped with a C18 (CLI) inverse column. One liter of sample was filtered at $0.02 \mathrm{MPa}$ onto a $25 \mathrm{~mm} \mathrm{GF/F}$ filter. Filters were stored at $-196{ }^{\circ} \mathrm{C}$ in liquid nitrogen. Extraction of pigments was conducted with cold methanol $\left(-20^{\circ} \mathrm{C}\right)$ for $12 \mathrm{~h}$. Pigment identification and quantification involved comparison with retention times, peak areas and adsorption spectra obtained using certified standard solutions from DHI Group, Denmark.

Samples for nutrient analysis were taken in $125 \mathrm{ml}$ polyethylene bottles, pre-washed with hydrochloric acid and deionised water and rinsed with in situ seawater immediately before sampling. Samples were stored at $-20^{\circ} \mathrm{C}$ in darkness until the analysis was carried out. A semi-automated system (Bran \& Luebbe, Autoanalyser II) was used to determine silicic acid $\left(\mathrm{Si}(\mathrm{OH})_{4}\right)$, nitrate $\left(\mathrm{NO}_{3}^{-}\right)$and phosphate $\left(\mathrm{PO}_{4}^{3-}\right)$ concentrations, with accuracies of $0.05 \mu \mathrm{M}, 0.05 \mu \mathrm{M}$ and $0.01 \mu \mathrm{M}$, respectively.

\subsection{Analysis of volatiles}

Bromocarbons were analysed using a purge-and-trap technique and GC-ECD (Chrompack CP 9000) modified after Pruvost et al. (1999). The purge-and-trap loop was altered and Valco valves were replaced by highly salt water resistant Swagelok models. Sampling devices were modified according to Bulsiewicz et al. (1998). These new sampling devices $(30 \mathrm{ml})$ were highly gas tight and enable a straightforward connection to the Niskin bottle and to the purge-andtrap loop respectively via Swagelok miniature quick connectors. The connector between the Niskin bottle and sampling device comprises a filter element with $15 \mu \mathrm{m}$ pore size, in order to remove larger particles. Samples were stored in the dark at $4{ }^{\circ} \mathrm{C}$ and analyzed within four hours of sampling. Volatiles were extracted by purging with ultra-pure nitrogen for $20 \mathrm{~min}$ at a flow of $90 \mathrm{ml} \mathrm{min}^{-1}$. Purging took place at ambient temperature in a purge chamber, which contained a glass frit (Pyrex 4). Reanalysis of already purged and analysed samples showed that purge efficiency was high and all volatiles were purged during the normal purging time of $20 \mathrm{~min}$. The gas flow was dried downstream using a condenser (held at $2^{\circ} \mathrm{C}$ ) and a magnesium perchlorate trap. Volatiles were concentrated in a stainless steel capillary tube $(150 \mathrm{~cm})$ at $-78^{\circ} \mathrm{C}$ and subsequently injected into a gas chromatographic column by thermodesorption $\left(100^{\circ} \mathrm{C}\right.$, backflush). Separation of the compounds was performed using a capillary column (fused silica megabore DB-624, 75 m, $0.53 \mathrm{~mm}$ id, $3 \mathrm{~mm}$ film thickness, J \& W Scientific, flow: $6 \mathrm{ml} \mathrm{min}{ }^{-1}$ ultra pure nitrogen) and a temperature program $\left(10 \mathrm{~min}\right.$ at $70^{\circ} \mathrm{C}$, rising for $8 \mathrm{~min}$ to $150^{\circ} \mathrm{C}$ and stable for 7 min at $150^{\circ} \mathrm{C}$ ). Quantification of volatiles was performed by external liquid standards (AccuStandard and Carlo Erba).
Liquid standards were diluted in seawater and treated like a normal sample.

\subsection{Statistics}

Cluster analysis (k-means algorithm) of the data set revealed that Sea Surface Temperature (SST) forms three distinct clusters, which were used to separate the water masses. We defined the recently upwelled water mass with sampling stations with a SST between $13.5^{\circ} \mathrm{C}$ and $15.2^{\circ} \mathrm{C}$. These stations were close to the coast of the Iberian Peninsula. The aged upwelled water mass corresponds to stations with a SST between $15.5^{\circ} \mathrm{C}$ and $17.7^{\circ} \mathrm{C}$. These stations were located either close to the coast line or in the filament. The open ocean water mass had SST ranging between $18.1^{\circ} \mathrm{C}$ and $20.8^{\circ} \mathrm{C}$ and all of these stations were located far off the Iberian coast. The three SST clusters were used for all subsequent data treatments (e.g. Pearson $r$ correlations). We tested the effect of tide and time of the day on bromocarbon concentration using a one-way ANOVA with subsequent post-hoc tests (Tukey's honestly significant difference). The software Statistica (Release 8.0) was used for all statistical tests and techniques.

\section{Results}

\subsection{Upwelling during the campaign}

The distribution of halocarbons in the Iberian peninsula upwelling system was one of the research topics of the MOUTON campaign in 2007. Water samples were taken in the upper $200 \mathrm{~m}$ of the water column along a north-to-south transect within the upwelling and along gradients from the coast to the open ocean. The sampling strategy was designed in due consideration of multidisciplinary interests, studying spatial and temporal variability of biological, physical and geochemical processes in the area. On board, satellite images were obtained for SST and Chl- $a$ concentration from the Moderate Resolution Imaging Spectroradiometer (MODIS aboard the NASA Aqua satellite). These images were used for adjustment of the sampling strategy. Both Chl- $a$ concentration and SST images indicated upwelling and the occurrence of a phytoplankton bloom with high daily variability along the coast off Portugal throughout the campaign. SST and Chl- $a$ distribution from a representative satellite image taken on 19 August is presented in Fig. 2. The SST image shows clear upwelling in the studied area (Fig. 2a). Distinctive upwelling took place along the Iberian Peninsula from Cap Finisterre to $37^{\circ} \mathrm{N}$ with highest intensity between $40^{\circ} \mathrm{N}$ and $42^{\circ} \mathrm{N}$. A clear temperature gradient was visible from the open ocean $\left(>18^{\circ} \mathrm{C}\right)$ towards the coast $\left(<15^{\circ} \mathrm{C}\right)$. Pronounced cold water filaments occurred at $38^{\circ} \mathrm{N}, 40^{\circ} \mathrm{N}$ and $42^{\circ} \mathrm{N}$. These mesoscale structures (typical life time of one week) are created by advection processes and transport nutrient enriched cold water masses at the surface from the Iberian coast towards the open ocean. The Chl- $a$ satellite 

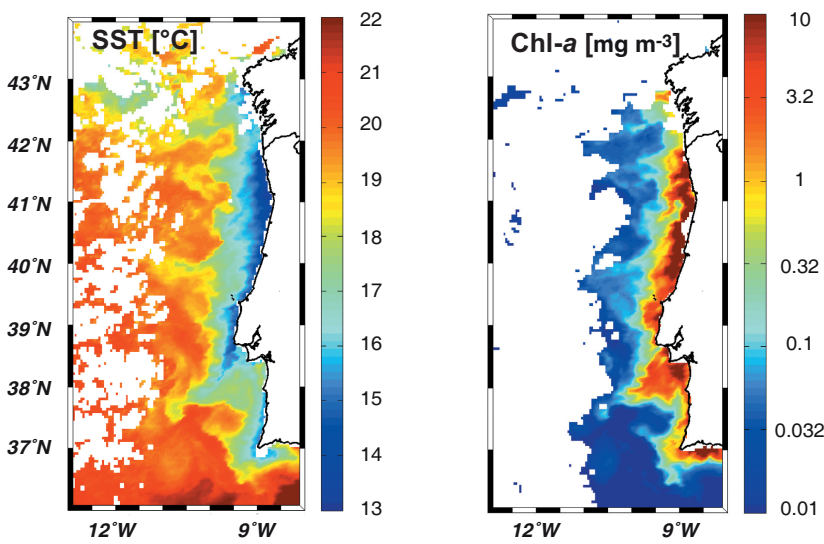

Fig. 2. Satellite images of sea surface temperature (SST) and Chl- $a$ concentration on 19 August 2007. Source: Data from the Moderate Resolution Imaging Spectroradiometer (MODIS) aboard the Aqua satellite (EOS-PM1, NASA). White is cloud cover. Left: SST [ $\left.{ }^{\circ} \mathrm{C}\right]$. Right: Chl- $a$ concentration $\left[\mathrm{mg} \mathrm{m}^{-3}\right.$ ].

images indicated elevated phytoplankton biomass along the Iberian Peninsula (Fig. 2b). Concentrations were highest near the coastline (above $2 \mathrm{mg} \mathrm{m}^{-3}$ ) and two orders of magnitude lower in the open ocean. Phytoplankton formed a meandering structure along the coast. During the last week of the campaign (4 to 9 September), upwelling conditions were still evident although wind velocity decreased (less than $10 \mathrm{~m} \mathrm{~s}^{-1}$ ) and SST increased by several degrees along the coast.

The campaign started with a north-to-south track (Fig. 1), which followed the $100 \mathrm{~m}$ bottom depth isoline and was located within a zone of intense upwelling (14 to 17 August). This track was chosen to investigate halocarbon dynamics within the maximum of phytoplankton density. A second transect (west-to-east track, Fig. 1) was performed along the $40^{\circ} \mathrm{N}$ latitude from the open ocean towards the upwelling (24 to 25 August). This track was chosen to investigate differences between coastal influenced upwelled waters and nutrient depleted open ocean waters. A distinct and newly developed offshore filament at $40.3^{\circ} \mathrm{N}$ with low SST values and high phytoplankton content was sampled from 6 to 9 September. Additionally, surface and depth samples were taken continuously at fixed stations over $30 \mathrm{~h}$ periods. The station at $\left(41^{\circ} \mathrm{N} ; 9^{\circ} \mathrm{W}\right)$ was located in recently upwelled water masses (20 to 21 August). The aged upwelled water mass was investigated at $40.3^{\circ} \mathrm{N}, 9.2^{\circ} \mathrm{W}$ (4 to 5 September). In the open ocean $\left(41^{\circ} \mathrm{N}, 10.5^{\circ} \mathrm{W}\right)$, samples were taken from 22 to 23 August.

\subsection{Spatial distribution}

A very patchy distribution of dibromomethane $\left(\mathrm{CH}_{2} \mathrm{Br}_{2}\right)$, bromodichloromethane $\left(\mathrm{CHBrCl}_{2}\right)$, dibromochloromethane $\left(\mathrm{CHBr}_{2} \mathrm{Cl}\right)$ and bromoform $\left(\mathrm{CHBr}_{3}\right)$ was recorded in the
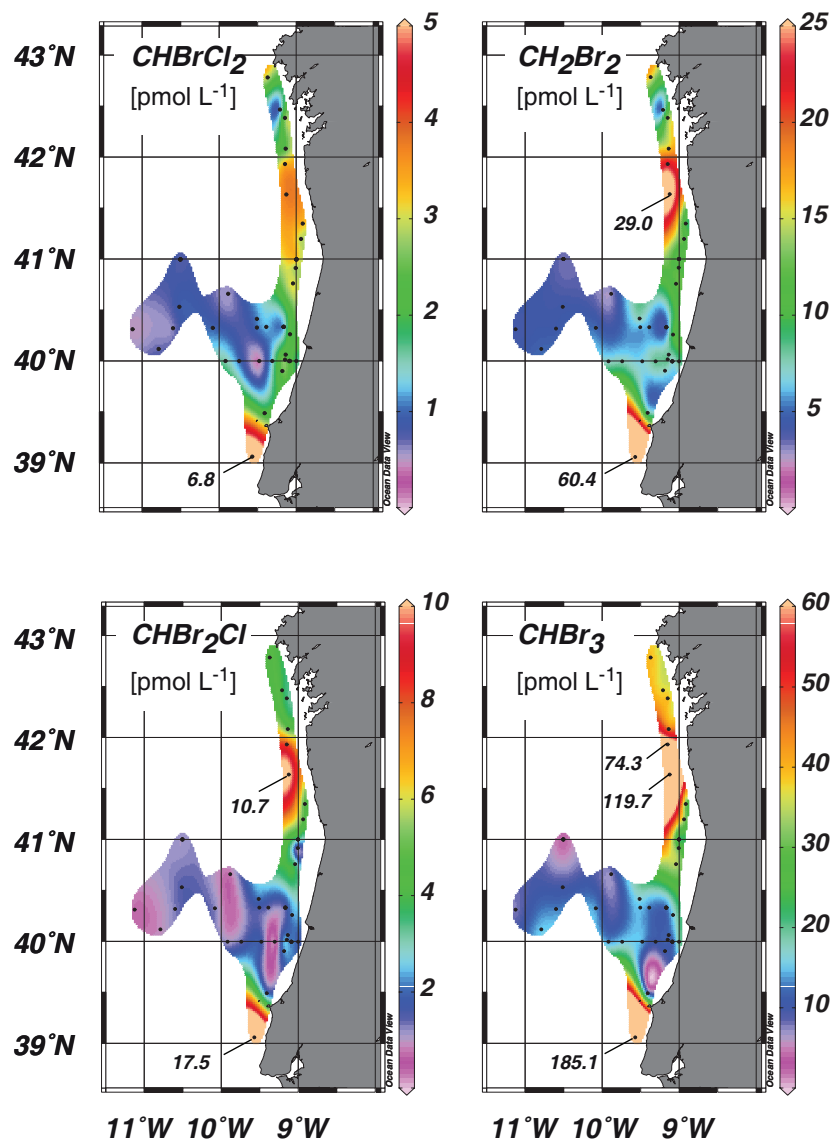

Fig. 3. Sea surface concentrations of bromocarbons in pmol $1^{-1}$ Bromodichloromethane $\left(\mathrm{CHBrCl}_{2}\right)$, dibromomethane $\left(\mathrm{CH}_{2} \mathrm{Br}_{2}\right)$, dibromochloromethane $\left(\mathrm{CHBr}_{2} \mathrm{Cl}\right)$ and bromoform $\left(\mathrm{CHBr}_{3}\right)$. Colour scales indicate different concentration ranges. Stations with values out of scale are labelled. Black dots are CTD stations.

studied area (Fig. 3). Distribution patterns of the four measured brominated compounds were similar. Generally, concentrations were higher along the coast and lower in the open ocean as well as in the phytoplankton enriched cold water filaments. The highest coastal values were found between $41^{\circ} \mathrm{N}$ and $42^{\circ} \mathrm{N}$ and around $39.5^{\circ} \mathrm{N}$. In these areas, surface concentrations were higher than $60 \mathrm{pmoll}^{-1}$ for $\mathrm{CHBr}_{3}$ and $25 \mathrm{pmoll}^{-1}$ for $\mathrm{CH}_{2} \mathrm{Br}_{2}$. In contrast, mean open ocean concentrations were $7.4 \mathrm{pmoll}^{-1}$ for $\mathrm{CHBr}_{3}$ and $4.8 \mathrm{pmoll}^{-1}$ for $\mathrm{CH}_{2} \mathrm{Br}_{2}$.

Cluster analysis of the data set revealed that SST formed three distinct clusters, which were used to classify different water masses (see methods). In order to evaluate processes in the biologically active upper water layers, the clustered data set was additionally divided into two groups (upper layer: surface layer to chlorophyll maximum layer; lower layers: below chlorophyll maximum layer). Integrated values are presented in Table 1 for bromocarbons and complementary variables. Salinity showed slightly lower values 
Table 1. The range (10th and 90th percentiles) and mean of bromocarbon concentrations and selected physical, chemical and biological variables in the Iberian upwelling. Data grouped by sampling depth (upper layers: surface to chlorophyll maximum; lower layer: below chlorophyll maximum) and water mass with indicated temperature anomalies (difference between SST of a water mass and all samples).

\begin{tabular}{|c|c|c|c|c|c|c|c|c|c|c|c|c|}
\hline \multicolumn{13}{|c|}{ Upper layers } \\
\hline & \multicolumn{4}{|c|}{ Recently upwelled } & \multicolumn{4}{|c|}{ Aged upwelled } & \multicolumn{4}{|c|}{ Open ocean } \\
\hline & 10th & 90th & mean & $\mathrm{N}$ & 10th & 90th & mean & $\mathrm{N}$ & 10th & 90th & mean & $\mathrm{N}$ \\
\hline $\mathrm{CH}_{2} \mathrm{Br}_{2}\left[\mathrm{pmol}^{-1}\right]$ & 5.4 & 15.2 & 9.8 & 51 & 4.6 & 22.8 & 11.8 & 58 & 2.7 & 6.9 & 4.8 & 33 \\
\hline $\mathrm{CHBrCl}_{2}\left[\mathrm{pmol}^{-1}\right]$ & 1.3 & 3.8 & 3.1 & 50 & 0.9 & 3.9 & 2.3 & 57 & 0.5 & 1.0 & 0.8 & 33 \\
\hline $\mathrm{CHBr}_{2} \mathrm{Cl}\left[\mathrm{pmol}^{-1}\right]$ & 0.6 & 5.1 & 3.2 & 51 & 0.0 & 8.2 & 3.3 & 58 & 0.5 & 2.2 & 1.3 & 33 \\
\hline $\mathrm{CHBr}_{3}\left[\mathrm{pmol}^{-1}\right]$ & 11.3 & 39.5 & 21.7 & 51 & 10.3 & 74.4 & 31.1 & 58 & 3.8 & 15.1 & 7.4 & 33 \\
\hline Chl- $a\left[\mathrm{mg} \mathrm{m}^{-3}\right]$ & 0.57 & 2.57 & 1.40 & 52 & 0.37 & 3.48 & 1.75 & 73 & 0.13 & 0.90 & 0.50 & 33 \\
\hline Chl- $b\left[\mathrm{mg} \mathrm{m}^{-3}\right]$ & $<$ LOD & 0.19 & 0.10 & 28 & $<$ LOD & 0.22 & 0.12 & 63 & $<$ LOD & 0.31 & 0.11 & 18 \\
\hline Chl-c2 $\left[\mathrm{mg} \mathrm{m}^{-3}\right]$ & $<$ LOD & 0.68 & 0.23 & 28 & $<$ LOD & 0.54 & 0.18 & 63 & $<\mathrm{LOD}$ & 0.20 & 0.05 & 18 \\
\hline Chl-c3 $\left[\mathrm{mg} \mathrm{m}^{-3}\right]$ & $<\mathrm{LOD}$ & 0.31 & 0.09 & 28 & $<\mathrm{LOD}$ & 0.28 & 0.11 & 63 & $<\mathrm{LOD}$ & 0.30 & 0.07 & 18 \\
\hline Fuco $\left[\mathrm{mg} \mathrm{m}^{-3}\right]$ & 0.25 & 2.49 & 0.91 & 28 & $<$ LOD & 2.04 & 0.80 & 63 & 0.02 & 0.21 & 0.09 & 18 \\
\hline But $\left[\mathrm{mg} \mathrm{m}^{-3}\right]$ & $<\mathrm{LOD}$ & 0.05 & 0.02 & 28 & $<\mathrm{LOD}$ & 0.08 & 0.04 & 63 & 0.01 & 0.12 & 0.06 & 18 \\
\hline Perid $\left[\mathrm{mg} \mathrm{m}^{-3}\right]$ & 0.03 & 0.15 & 0.09 & 28 & 0.02 & 0.22 & 0.10 & 63 & $<\mathrm{LOD}$ & 0.11 & 0.03 & 18 \\
\hline $\operatorname{Hex}\left[\mathrm{mg} \mathrm{m}^{-3}\right]$ & 0.01 & 0.16 & 0.06 & 28 & 0.02 & 0.26 & 0.12 & 63 & 0.01 & 0.52 & 0.18 & 18 \\
\hline Diadino $\left[\mathrm{mg} \mathrm{m}^{-3}\right]$ & 0.03 & 0.25 & 0.10 & 28 & 0.03 & 0.21 & 0.11 & 63 & 0.01 & 0.05 & 0.03 & 18 \\
\hline Allo $\left[\mathrm{mg} \mathrm{m}^{-3}\right]$ & $<$ LOD & 0.06 & 0.02 & 28 & $<\mathrm{LOD}$ & 0.05 & 0.02 & 63 & $<\mathrm{LOD}$ & 0.02 & 0.01 & 18 \\
\hline Lut $\left[\mathrm{mg} \mathrm{m}^{-3}\right]$ & $<\mathrm{LOD}$ & 0.04 & 0.01 & 28 & $<\mathrm{LOD}$ & 0.04 & 0.01 & 63 & $<\mathrm{LOD}$ & 0.00 & 0.00 & 18 \\
\hline Zea $\left[\mathrm{mg} \mathrm{m}^{-3}\right]$ & $<$ LOD & 0.06 & 0.03 & 28 & $<$ LOD & 0.09 & 0.04 & 63 & 0.05 & 0.11 & 0.08 & 18 \\
\hline B-car $\left[\mathrm{mg} \mathrm{m}^{-3}\right]$ & $<$ LOD & 0.13 & 0.05 & 28 & $<$ LOD & 0.11 & 0.04 & 63 & $<$ LOD & 0.06 & 0.02 & 18 \\
\hline Salinity [PSU] & 35.64 & 35.72 & 35.68 & 52 & 35.61 & 35.76 & 35.69 & 73 & 35.80 & 36.04 & 35.92 & 33 \\
\hline Density $[\sigma]$ & 26.49 & 26.85 & 26.68 & 52 & 26.08 & 26.68 & 26.34 & 73 & 25.45 & 26.63 & 26.08 & 33 \\
\hline Oxygen $\left[\mu \mathrm{mol} 1^{-1}\right]$ & 191.28 & 278.50 & 224.43 & 52 & 241.93 & 306.92 & 267.62 & 73 & 225.54 & 252.38 & 239.82 & 33 \\
\hline $\mathrm{AOU}\left[\mu \mathrm{mol} 1^{-1}\right]$ & -21.87 & 63.64 & 32.91 & 52 & -55.60 & 8.60 & -14.25 & 73 & -4.86 & 5.78 & 1.18 & 33 \\
\hline Nitrate $\left[\mu \mathrm{mol} 1^{-1}\right]$ & 0.68 & 11.10 & 7.35 & 44 & $<$ LOD & 5.09 & 1.55 & 71 & $<$ LOD & 0.95 & 0.37 & 30 \\
\hline Silicate $\left[\mu \mathrm{mol} 1^{-1}\right]$ & 0.70 & 5.83 & 3.13 & 45 & 0.54 & 1.97 & 1.05 & 72 & 0.91 & 1.94 & 1.27 & 31 \\
\hline Phosphate $\left[\mu \mathrm{mol}^{-1}\right]$ & 0.11 & 0.97 & 0.62 & 44 & 0.05 & 0.38 & 0.18 & 70 & 0.02 & 0.17 & 0.08 & 33 \\
\hline $\mathrm{N}^{*}\left[\mu \mathrm{mol} 1^{-1}\right]$ & -2.11 & 1.87 & 0.19 & 43 & 0.33 & 2.24 & 1.36 & 69 & 1.46 & 2.80 & 2.07 & 30 \\
\hline
\end{tabular}

of about 35.7 in the upwelling (both recent and aged upwelling) and elevated values in the open ocean (35.9). In addition, nutrients showed a clear decreasing concentration gradient from the recently upwelled water masses to aged upwelled water masses to open ocean water masses. Pigment concentrations were higher in both upwelled water masses. For example, values for the diatom marker pigment fucoxanthin were one order of magnitude higher in recently and aged upwelled waters compared to values in open ocean waters. The spatial distribution of halocarbons in the biologically active upper layers was characterized by a clear concentration gradient between upwelled and open ocean water masses. Mean values were about 2 to 4.6 times lower in the open ocean compared to upwelled waters. The high variability of halocarbon concentrations during the campaign is illustrated in Fig. 4, showing mean values of bromocarbons and Chl- $a$ concentration for upper water layers, SST, bottom depth (reflecting roughly the distance to the coast), and tidal amplitude. Bromocarbon concentrations were highest during the first week of the cruise, with elevated concentrations on 15 and 17 August. Both sampling sites were located in aged upwelled waters. Higher bromocarbon concentrations were generally measured in recently and aged upwelled water masses, which are characterized by shallow bottom depths, elevated Chl- $a$ concentrations and low SST. However, the high variability of bromocarbon concentrations cannot be explained strictly by the variance in SST or Chl$a$ concentrations. At the stations where measurements were conducted over a daily cycle, slight concentration variations were visible without a clear diurnal pattern. The effect of the sampling period on bromocarbon variability is discussed in more detail in Sect. 4.3. 
Table 1. Continued.

\begin{tabular}{|c|c|c|c|c|c|c|c|c|c|c|c|c|}
\hline \multicolumn{13}{|c|}{ Lower layers } \\
\hline & \multicolumn{4}{|c|}{ Recently upwelled } & \multicolumn{4}{|c|}{ Aged upwelled } & \multicolumn{4}{|c|}{ Open ocean } \\
\hline & 10th & 90th & mean & $\mathrm{N}$ & 10th & 90th & mean & $\mathrm{N}$ & 10th & 90th & mean & $\mathrm{N}$ \\
\hline $\mathrm{CH}_{2} \mathrm{Br}_{2}\left[\mathrm{pmoll}^{-1}\right]$ & 4.8 & 10.8 & 7.8 & 30 & 2.6 & 10.6 & 6.6 & 34 & 2.8 & 6.4 & 4.2 & 16 \\
\hline $\mathrm{CHBrCl}_{2}\left[\mathrm{pmol}^{-1}\right]$ & 1.8 & 4.1 & 3.0 & 31 & 0.9 & 3.6 & 2.3 & 34 & 0.5 & 1.0 & 0.8 & 16 \\
\hline $\mathrm{CHBr}_{2} \mathrm{Cl}\left[\mathrm{pmol}^{-1}\right]$ & 0.5 & 4.0 & 2.8 & 31 & 0.0 & 3.3 & 1.8 & 34 & 0.4 & 1.6 & 1.1 & 16 \\
\hline $\mathrm{CHBr}_{3}\left[\mathrm{pmol}^{-1}\right]$ & 6.0 & 15.1 & 11.9 & 31 & 3.3 & 17.3 & 9.5 & 34 & 2.1 & 5.1 & 3.5 & 16 \\
\hline Chl- $a\left[\mathrm{mg} \mathrm{m}^{-3}\right]$ & 0.13 & 0.48 & 0.28 & 32 & 0.08 & 0.83 & 0.39 & 45 & 0.05 & 0.20 & 0.08 & 16 \\
\hline Chl- $b\left[\mathrm{mg} \mathrm{m}^{-3}\right]$ & $<$ LOD & 0.12 & 0.03 & 8 & $<\mathrm{LOD}$ & 0.09 & 0.04 & 24 & & & & 0 \\
\hline Chl-c2 $\left[\mathrm{mg} \mathrm{m}^{-3}\right]$ & 0.03 & 0.17 & 0.07 & 8 & $<\mathrm{LOD}$ & 0.10 & 0.03 & 24 & & & & 0 \\
\hline Chl-c3 $\left[\mathrm{mg} \mathrm{m}^{-3}\right]$ & 0.02 & 0.08 & 0.04 & 8 & $<\mathrm{LOD}$ & 0.12 & 0.04 & 24 & & & & 0 \\
\hline Fuco $\left[\mathrm{mg} \mathrm{m}^{-3}\right]$ & 0.13 & 0.72 & 0.33 & 8 & 0.05 & 0.55 & 0.23 & 24 & & & & 0 \\
\hline But $\left[\mathrm{mg} \mathrm{m}^{-3}\right]$ & $<\mathrm{LOD}$ & 0.02 & 0.01 & 8 & $<\mathrm{LOD}$ & 0.03 & 0.01 & 24 & & & & 0 \\
\hline Perid $\left[\mathrm{mg} \mathrm{m}^{-3}\right]$ & $<\mathrm{LOD}$ & 0.09 & 0.03 & 8 & $<\mathrm{LOD}$ & 0.07 & 0.03 & 24 & & & & 0 \\
\hline $\operatorname{Hex}\left[\mathrm{mg} \mathrm{m}^{-3}\right]$ & $<\mathrm{LOD}$ & 0.02 & 0.01 & 8 & $<\mathrm{LOD}$ & 0.06 & 0.03 & 24 & & & & 0 \\
\hline Diadino $\left[\mathrm{mg} \mathrm{m}^{-3}\right]$ & 0.01 & 0.07 & 0.03 & 8 & $<\mathrm{LOD}$ & 0.04 & 0.03 & 24 & & & & 0 \\
\hline Allo $\left[\mathrm{mg} \mathrm{m}^{-3}\right]$ & $<$ LOD & 0.06 & 0.01 & 8 & $<$ LOD & 0.01 & 0.00 & 24 & & & & 0 \\
\hline Lut $\left[\mathrm{mg} \mathrm{m}^{-3}\right]$ & $<\mathrm{LOD}$ & 0.02 & $<\mathrm{LOD}$ & 8 & $<\mathrm{LOD}$ & 0.03 & 0.01 & 24 & & & & 0 \\
\hline $\mathrm{Zea}\left[\mathrm{mg} \mathrm{m}^{-3}\right]$ & $<\mathrm{LOD}$ & 0.04 & 0.01 & 8 & $<\mathrm{LOD}$ & 0.03 & 0.01 & 24 & & & & 0 \\
\hline B-car $\left[\mathrm{mg} \mathrm{m}^{-3}\right]$ & $<\mathrm{LOD}$ & 0.05 & 0.01 & 8 & $<\mathrm{LOD}$ & 0.04 & 0.01 & 24 & & & & 0 \\
\hline Salinity [PSU] & 35.67 & 35.82 & 35.76 & 32 & 35.70 & 35.82 & 35.77 & 45 & 35.72 & 35.80 & 35.76 & 16 \\
\hline Density $[\sigma]$ & 26.92 & 27.05 & 26.99 & 32 & 26.80 & 27.05 & 26.94 & 45 & 26.90 & 27.05 & 27.01 & 16 \\
\hline Oxygen $\left[\mu \mathrm{mol} 1^{-1}\right]$ & 154.62 & 217.53 & 183.58 & 32 & 163.91 & 228.17 & 199.83 & 45 & 221.03 & 236.60 & 230.23 & 16 \\
\hline $\mathrm{AOU}\left[\mu \mathrm{mol} 1^{-1}\right]$ & 52.26 & 107.21 & 80.14 & 32 & 1.31 & 98.91 & 54.90 & 45 & 24.65 & 43.11 & 33.73 & 16 \\
\hline Nitrate $\left[\mu \mathrm{mol}^{-1}\right]$ & 8.49 & 14.96 & 12.50 & 27 & 6.47 & 13.52 & 9.74 & 44 & 4.80 & 10.20 & 8.08 & 16 \\
\hline Silicate $\left[\mu \mathrm{mol} \mathrm{L}^{-1}\right]$ & 3.24 & 8.07 & 5.82 & 27 & 1.93 & 7.32 & 4.29 & 43 & 1.97 & 5.02 & 3.25 & 16 \\
\hline Phosphate $\left[\mu \mathrm{moll}^{-1}\right]$ & 0.60 & 1.03 & 0.86 & 27 & 0.45 & 0.92 & 0.68 & 43 & 0.31 & 0.71 & 0.53 & 16 \\
\hline $\mathrm{N}^{*}\left[\mu \mathrm{mol} 1^{-1}\right]$ & -0.13 & 2.95 & 1.57 & 27 & 0.69 & 2.79 & 1.67 & 43 & 1.95 & 2.96 & 2.52 & 16 \\
\hline
\end{tabular}

Chl- $a$ (chlorophyll- $a$ ), Chl- $b$ (chlorophyll- $b$ ), Chl-c2 (chlorophyll- $c$ 2), Chl-c3 (chlorophyll- $c 3$ ), Fuco (fucoxanthin), But (19'-butanoyl-fucoxanthin), Perid (peridin), Hex (19'hexanoyl-fucoxanthin), Diadino (diadinoxanthin), Allo (alloxanthin), Lut (lutein), Zea (zeaxanthin), B-car (beta-carotene)

\subsection{Vertical distribution of brominated halocarbons and environmental parameters}

Concentrations of bromocarbons were generally elevated in the upper water layers (Table 1). This is illustrated in depth profiles from three representative fixed stations, obtained during daily cycles, which provide more detailed vertical resolution (Fig. 5). The variables Chl- $a$, $\mathrm{N}^{*}$ and AOU are presented to evaluate whether phytoplankton could be a source of bromocarbons: Chl- $a$, as a general marker for the occurrence of phytoplankton, the apparent oxygen utilisation (AOU), which is influenced by biological oxygen production (photosynthesis) or consumption (respiration), and the quasiconservative tracer $\mathrm{N}^{*}$ (introduced by Gruber and Sarmiento, 1997), which is a linear combination of nitrate and phosphate. Since stratification influences chemical and biological properties of the water column, density $(\sigma)$ is the critical parameter for evaluation of the vertical distribution of these parameters.
At the fixed station in the recently upwelled water mass, the density plot revealed intense mixing in the first $15 \mathrm{~m}$ without a clear pycnocline (Fig. 5b). Chl- $a$ values were higher in the upper $25 \mathrm{~m}\left(1.4 \mathrm{mg} \mathrm{m}^{-3}\right.$; Fig. $\left.5 \mathrm{a}\right)$, followed by a moderate concentration gradient towards lowest Chl- $a$ values below $43 \mathrm{~m}$. AOU values were negatively correlated to Chl- $a$, with lowest values in the upper $25 \mathrm{~m}$ and high values in deep samples. $\mathrm{N}^{*}$ displayed the same pattern as the AOU with a minimum in the upper $25 \mathrm{~m}$ (nitrate loss) followed by a clear gradient towards maximum values (nitrate production) below $43 \mathrm{~m}$. The high Chl- $a$ values, low AOU and low $\mathrm{N}^{*}$ values observed in the upper $25 \mathrm{~m}$ were indicative of oxygen production and nitrate uptake, likely due to photoautotrophic processes. Below $43 \mathrm{~m}$, the low Chl- $a$, high AOU, and high $\mathrm{N}^{*}$ reflected considerable respiration by heterotrophic processes. In the biologically active upper water layers, bromocarbon concentrations were elevated and decreased constantly to low levels with depth. $\mathrm{CH}_{2} \mathrm{Br}_{2}$ and $\mathrm{CHBr}_{3}$ showed clear maxima at the depth of the Chl- $a$ maximum. Daily 
Table 2. Comparison of bromocarbon concentrations in different marine regions. Mean values in pmol $1^{-1}$.

\begin{tabular}{|c|c|c|c|c|c|c|c|c|}
\hline & $\begin{array}{l}\text { African } \\
\text { coastal } \\
\text { upwelling }\end{array}$ & $\begin{array}{l}\text { Mauritanian } \\
\text { upwelling }\end{array}$ & $\begin{array}{l}\text { African } \\
\text { coastal } \\
\text { upwelling }\end{array}$ & $\begin{array}{l}\text { North east } \\
\text { Atlantic }\end{array}$ & $\begin{array}{l}\text { Iberian } \\
\text { upwelling }\end{array}$ & $\begin{array}{l}\text { English } \\
\text { Channel }\end{array}$ & Irish Sea & $\begin{array}{l}\text { Antarctic } \\
\text { waters }\end{array}$ \\
\hline & $\begin{array}{l}25^{\circ} \mathrm{N} \\
16^{\circ} \mathrm{W} \\
(3 / 1985) \\
\text { Class and } \\
\text { Ballschmiter } \\
(1988)\end{array}$ & $\begin{array}{l}17-20.5^{\circ} \mathrm{N} \\
16-19^{\circ} \mathrm{W} \\
(4-5 / 2005) \\
\text { Quack et al. } \\
(2007)\end{array}$ & $\begin{array}{r}16-35^{\circ} \mathrm{N} \\
14-24^{\circ} \mathrm{W} \\
(5-6 / 2007) \\
\text { Carpen }\end{array}$ & $\begin{array}{l}53-59^{\circ} \mathrm{N} \\
7-13^{\circ} \mathrm{W} \\
(6-7 / 2006) \\
\text { al. }(2009)\end{array}$ & $\begin{array}{l}39-43^{\circ} \mathrm{N} \\
9-11^{\circ} \mathrm{W} \\
(8-9 / 2007) \\
\text { this work }\end{array}$ & $\begin{array}{l}50^{\circ} \mathrm{N} \\
4^{\circ} \mathrm{W} \\
(2006) \\
\text { Jones et al. } \\
(2009)\end{array}$ & $\begin{array}{l}53^{\circ} \mathrm{N} \\
4^{\circ} \mathrm{W} \\
(2004-2005) \\
\text { Bravo- } \\
\text { Linares } \\
\text { and Mudge } \\
(2009)\end{array}$ & $\begin{array}{l}70-72^{\circ} \mathrm{S} \\
9-11^{\circ} \mathrm{W} \\
(12 / 2003) \\
\text { Carpenter et } \\
\text { al. }(2007)\end{array}$ \\
\hline $\mathrm{CH}_{2} \mathrm{Br}_{2}$ & $5.77^{\mathrm{a}}$ & $\begin{array}{l}4.9^{\mathrm{a}} \\
5.8^{\mathrm{b}}\end{array}$ & $\begin{array}{l}3.4^{\mathrm{c}} \\
3^{\mathrm{d}} \\
1.4^{\mathrm{e}}\end{array}$ & $\begin{array}{l}1.1^{\mathrm{e}} \\
1.9^{\mathrm{f}} \\
15.6^{\mathrm{g}}\end{array}$ & $\begin{array}{l}11.8^{\mathrm{h}} \\
7.4^{\mathrm{i}}\end{array}$ & $\begin{array}{l}11.8^{\mathrm{k}} \\
22^{\mathrm{l}}\end{array}$ & $5.45^{\mathrm{g}}$ & \\
\hline $\mathrm{CHBrCl}_{2}$ & $6.1^{\mathrm{a}}$ & & & & $\begin{array}{l}3.0^{\mathrm{h}} \\
2.9^{\mathrm{i}}\end{array}$ & & $5.06^{\mathrm{g}}$ & \\
\hline $\mathrm{CHBr}_{2} \mathrm{Cl}$ & $9.6^{\mathrm{a}}$ & & & & $\begin{array}{l}3.7^{\mathrm{h}} \\
2.6^{\mathrm{i}}\end{array}$ & & $17.3^{\mathrm{g}}$ & \\
\hline $\mathrm{CHBr}_{3}$ & $23.74^{\mathrm{a}}$ & $\begin{array}{l}10.7^{\mathrm{a}} \\
9^{\mathrm{b}}\end{array}$ & $\begin{array}{l}11.5^{\mathrm{c}} \\
14.4^{\mathrm{d}} \\
3.5^{\mathrm{e}}\end{array}$ & $\begin{array}{l}3.4^{\mathrm{e}} \\
6.7^{\mathrm{f}} \\
68.3^{\mathrm{g}}\end{array}$ & $\begin{array}{l}30.0^{\mathrm{h}} \\
11.6^{\mathrm{i}}\end{array}$ & $\begin{array}{l}217.4^{\mathrm{k}} \\
343.2^{1}\end{array}$ & $214.23^{\mathrm{g}}$ & $56.7^{\mathrm{g}}$ \\
\hline
\end{tabular}

${ }^{\mathrm{a}}$ depth $0-12 \mathrm{~m} ;{ }^{\mathrm{b}}$ depth $14-50 \mathrm{~m} ;{ }^{\mathrm{c}}$ upwelling; ${ }^{\mathrm{d}}$ Canary; ${ }^{\mathrm{e}}$ open ocean; ${ }^{\mathrm{f}}$ shelf and far coast; ${ }^{\mathrm{g}}$ coastal; ${ }^{\mathrm{h}}$ upwelling, upper layers; ${ }^{\mathrm{i}}$ upwelling, lower layers; ${ }^{\mathrm{k}}$ shore at high tide;

1 shore at low tide

variances of $\mathrm{CHBr}_{2} \mathrm{Cl}$ in the surface layer were high compared to the low concentration gradient in the water column.

At the fixed station in the aged upwelled water mass, the water column was stratified with a marked gradient from the surface to $33 \mathrm{~m}$ depth (Fig. 5f). The highest Chl- $a$ values for the Iberian upwelling were found in aged upwelled water masses (Fig. 4). At the representative fixed station, the highest Chl- $a$ values were recorded at $20 \mathrm{~m}$, together with low $\mathrm{N}^{*}$ values (nitrate loss) and negative AOU values (photosynthetic oxygen production, Fig. 5e, f). Although we recorded highest bromocarbon concentrations in the aged upwelled water masses, these values were restricted to a few sampling sites only (Fig. 3). Bromocarbon values at the fixed station in the aged upwelled water mass were lower than average concentrations for this water mass (Table 1), but showed a typical gradient with low values in the deeper levels. For instance, the highest $\mathrm{CHBr}_{3}$ concentrations at $20 \mathrm{~m}$ (12.4 pmol $^{-1}$, Fig. 5h) were about three times higher than at $90 \mathrm{~m}$, but only half of the mean concentrations in the upwelling (integrated over upper layers, Table 1).

At the fixed station in the open ocean, the water column was clearly stratified and showed a deep Chl- $a$ maximum at $74 \mathrm{~m}$ (Fig. 5i-j). The pycnocline coincided with highest phytoplankton density and activity (Chl- $a$ maximum, N* minimum, low AOU; Fig. 5i-j). Bromocarbon concentrations were low compared to typical upwelling concentrations (Table 1). $\mathrm{CHBr}_{3}$ concentrations were highest at the Chl$a$ maximum $\left(5.7 \mathrm{pmol}^{-1}\right)$ at $74 \mathrm{~m}$. The highest concentrations of $\mathrm{CH}_{2} \mathrm{Br}_{2}\left(5.3 \mathrm{pmol}^{-1}\right)$ and $\mathrm{CHBrCl}_{2}\left(0.9 \mathrm{pmol}^{-1}\right)$ were measured between the Chl- $a$ maximum and the end of the thermocline (from 74 to $110 \mathrm{~m}$ ). $\mathrm{CHBr}_{2} \mathrm{Cl}$ showed high daily variance and the highest values above the Chl- $a$ maximum $\left(1.7 \mathrm{pmol}^{-1}\right.$ at $\left.51 \mathrm{~m}\right)$.

\section{Discussion}

\subsection{Bromocarbon sources}

Bromocarbon concentrations in the Iberian upwelling system were low compared to other productive marine areas (Table 2). To the best of our knowledge, only three previous studies have focused on upwelling regions. Class and Ballschmiter (1988) measured bromocarbons in air and water samples near the Western African coast $\left(6-30^{\circ} \mathrm{N}\right.$, $\left.16^{\circ} \mathrm{W}\right)$. In the same area $\left(17-20.5^{\circ} \mathrm{N}, 16-19^{\circ} \mathrm{W}\right)$, Quack et al. (2007) studied the oceanic distribution of $\mathrm{CH}_{2} \mathrm{Br}_{2}$ and $\mathrm{CHBr}_{3}$. While $\mathrm{CH}_{2} \mathrm{Br}_{2}$ values were similar in these two studies, reported $\mathrm{CHBr}_{3}$ values were significantly lower in the latter study. Again in the Mauritanian upwelling, Carpenter et al. (2009) presented sea surface concentrations for the same compounds, which were comparable with those from Quack et al. (2007). Both of these studies concluded that bromocarbon concentrations were elevated in the upwelling as compared to open ocean concentrations, but lower than concentrations known from macroalgae-influenced coastal regions. Our results from the Iberian upwelling system also exhibit a marked gradient of bromocarbon concentrations from the upwelling towards the open ocean. However, bromoform concentrations (mean $30 \mathrm{pmoll}^{-1}$ for the entire upwelling) 


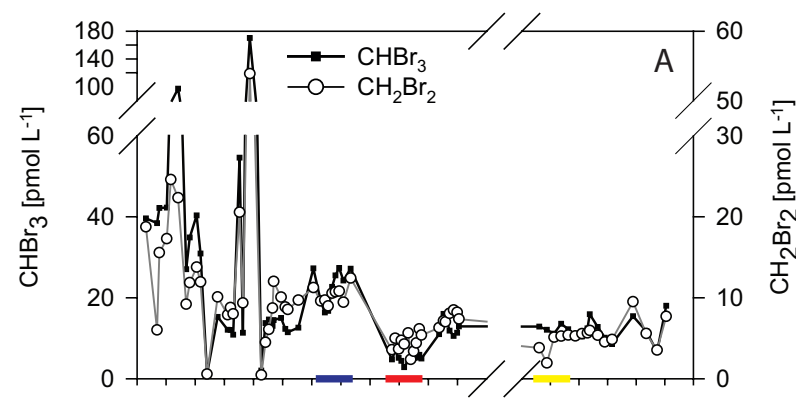

regions are pronounced "hot spots" for halocarbon formation (Quack et al., 2004).

The relatively low bromocarbon concentrations measured in different upwelling areas question the importance of phytoplankton as a significant halocarbon source, in marked contrast with studies showing correlations between high concentrations of various halocarbons and the growth of microalgae (Krysell, 1991; Hughes et al., 2009; Klick and Abrahamsson, 1992; Moore and Tokarczyk, 1993). For example, $\mathrm{CHBr}_{3}$ values reported by Carpenter et al. (2007) for phytoplanktonrich Antarctic surface waters were about twice as high as in the Iberian upwelling. The discrepancy between expected and observed concentrations in upwelling areas investigated so far is likely due to the fact that halocarbon production is highly species specific (e.g. Moore et al., 1996). Several studies have shown that phytoplankton species from distant phyla are effective halocarbon sources, but that halocarbon production can vary considerably between members of the same genus (Sturges et al., 1992; Tokarczyk and Moore, 1994; Moore et al., 1996). Hill and Manley (2009) demonstrated that phytoplankton species with different temperature preferences show different halocarbon production capacities: polar diatom species showed generally high bromoperoxidase activity, while most temperate and tropical species investigated exhibited little or no bromoperoxidase activity.

Phytoplankton composition in the investigated upwelling regions was therefore presumably unfavourable for high bromocarbon production. Differences in published halocarbon concentrations in several areas may also be partly due to temporal variability of the strength of the source. Several studies have demonstrated that seasonality of halocarbon production can be explained by enhanced tissue decay during summer (Goodwin et al., 1997a; Klick, 1992), stimulated halocarbon formation by macroalgae under high light conditions (e.g. Carpenter et al., 2005; Nightingale et al., 1995; Pedersen et al., 1996) or periodic phytoplankton blooms (e.g. Hughes et al., 2009). Thus, seasonality complicates direct comparison of different studies and the evaluation of local source strengths only gives a pattern for a given ecosystem.

\subsection{Evidence for halocarbon production by phytoplankton}

Although the measured bromocarbon concentrations were lower than expected in the phytoplankton-rich upwelling, we found evidence for a phytoplanktonic source in the studied area. Spatial (Figs. 2 and 3) and vertical (Fig. 5) distributions of halocarbons and Chl- $a$ showed similarities. Correlation analyses for brominated compounds with environmental variables suggest a phytoplanktonic source offshore in the Iberian peninsula (Fig. 6). For the correlation analysis, the data set was clustered according to water masses. Significant Pearson $r$ correlations $(p<0.05)$ with environmental variables were plotted for each bromocarbon. In addition to the biological markers $\mathrm{N}^{*}$ and AOU, we used light transmission 


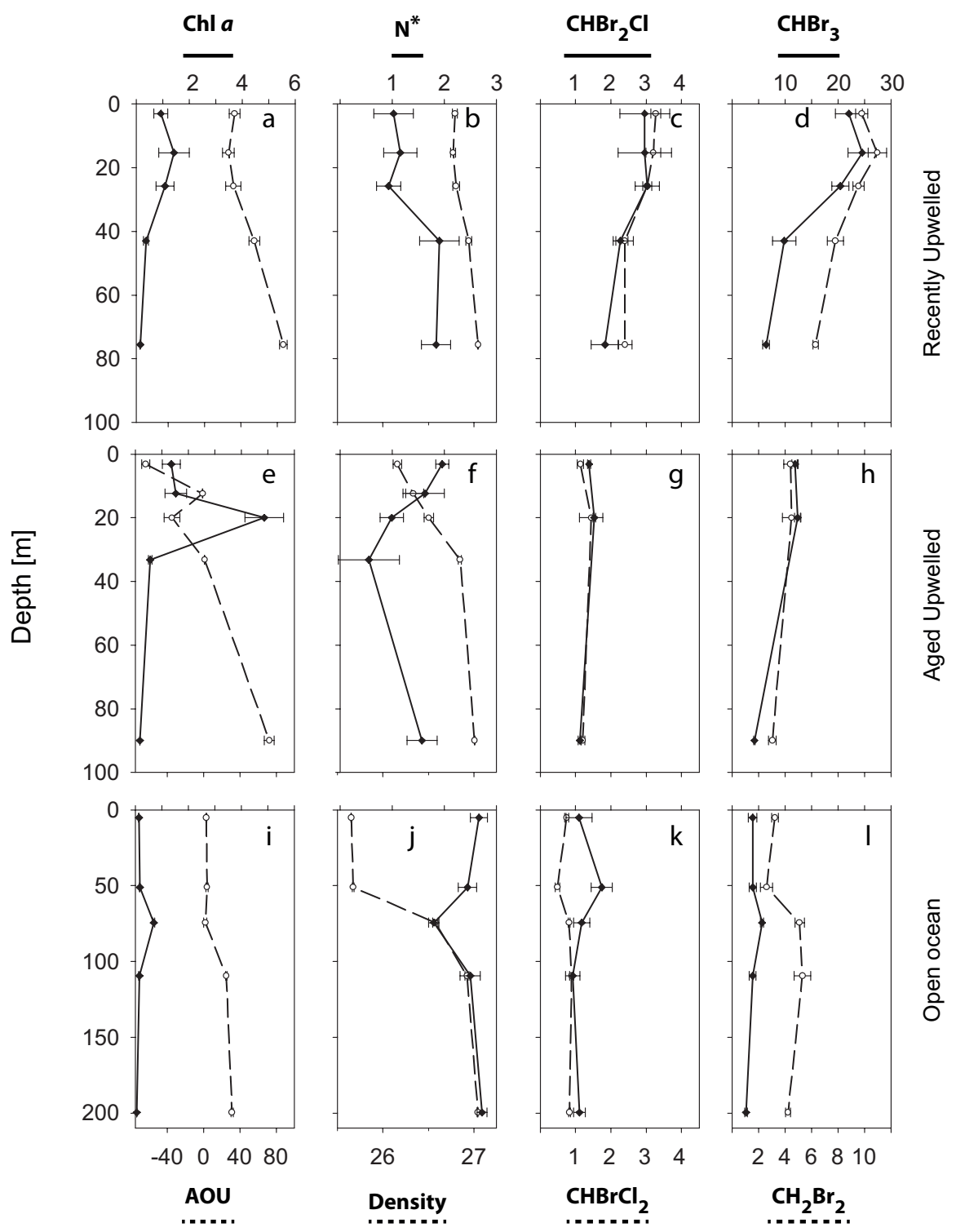

Fig. 5. Depth profiles of chlorophyll $a\left[\mathrm{mg} \mathrm{m}^{-3}\right]$, AOU $\left[\mu \mathrm{mol} \mathrm{L}^{-1}\right], \mathrm{N}^{*}\left[\mu \mathrm{mol} \mathrm{l}^{-1}\right]$, density $[\sigma]$ and brominated halocarbons $\left[\mathrm{pmol} \mathrm{l}^{-1}\right]$ at three fixed stations. Variables are expressed as means of all samples during a daily cycle at the different depths (surface, upper thermocline, chlorophyll maximum, lower thermocline and bottom) and water mass: (a)-(d) Recently upwelled waters. (e)-(h) Aged upwelled waters. (i)-(l) Open ocean waters. Full lines use upper x-axis. Dashed lines refer to lower x-axis. Error bars show S.E.

as a rough approximation for plankton density, since elevated plankton densities induce a decrease in light transmission. Finally, correlations to marker pigments were used to identify phytoplankton groups for the production of halocarbons.

The most obvious observation is that correlations from bromocarbons with environmental variables were strongest in the open ocean. Correlations were less pronounced in the recently upwelled water mass (strongest for bromoform) and weak in the aged upwelled water mass. A different species composition, which is influenced by changing abiotic parameters during the ageing of upwelled waters, might explain changing correlation patterns in the different water masses for the different bromocarbons.
Negative correlations of $\mathrm{CHBr}_{3}$ to the biological markers $\mathrm{N}^{*}$ and $\mathrm{AOU}$ in the open ocean revealed that elevated bromocarbon concentrations were related to nitrate uptake and biological oxygen production, both typical for the occurrence of phytoplankton. Negative correlations to light transmission were also found for all bromocarbons in the open ocean. Assuming high phytoplankton densities caused a decreased light transmission, negative correlations to light transmission support the idea of a phytoplankton source. The diversity of correlated pigments emphasizes the involvement of different phytoplankton groups in the formation of bromocarbons. Correlations were highest to fucoxanthin (marker for diatoms), Chl- $b$ (marker for 

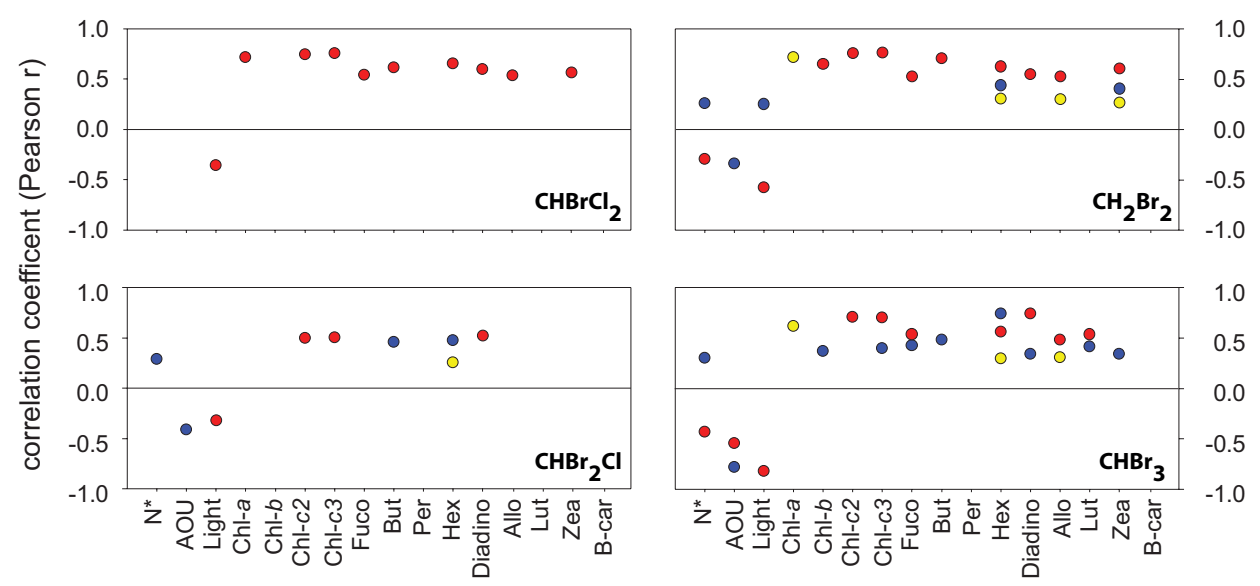

Fig. 6. Results of cross-tabulation tables of Pearson $r$ correlation coefficients for bromocarbons vs. quasi biological markers ( $N^{*}, A O U$ and light transmission) and marker pigments. Data are clustered into three water masses: Recently upwelled waters (blue), aged upwelled waters (yellow) and open ocean waters (red). For the abbreviation of the marker pigments see Table 1.
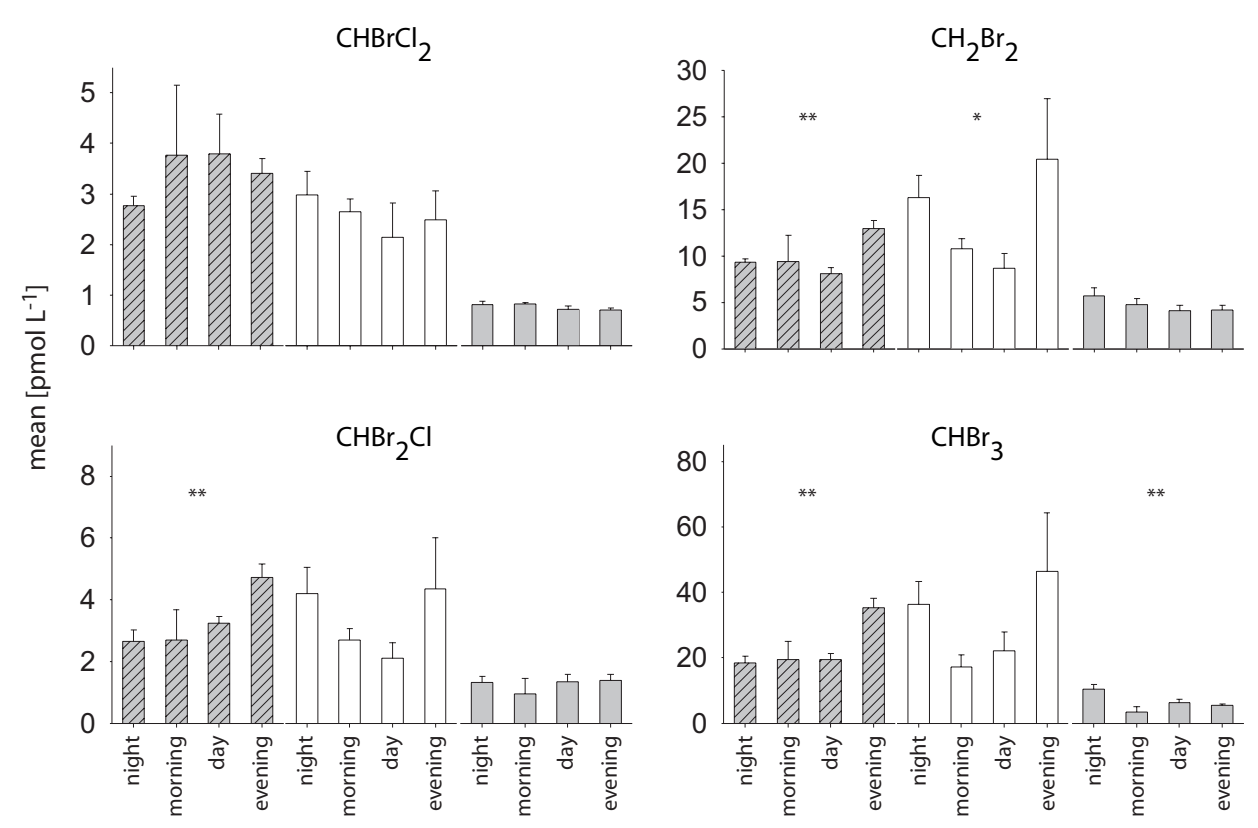

Fig. 7. Bromocarbon concentrations against time of the day in the upper water layers (surface to chlorophyll maximum). Data are clustered into three water masses: recently upwelled waters (gray shaded), aged upwelled waters (white) and open ocean waters (gray). Mean values at four different times (night, day, and the intermediate morning and evening). Night and day were defined as two hours before sunrise and sunset, respectively. Confidence levels: * significant at $90 \%$. ** significant at $95 \%$.

green algae and for prochlorophytes), as well as Chl-c3 and 19'-hexanoyloxyfucoxanthin (marker for prymnesiophytes). Hence these plankton groups might have played key roles in the biological production.

Correlations of $\mathrm{CHBr}_{2} \mathrm{Cl}$ and $\mathrm{CHBrCl}_{2}$ to environmental variables were less pronounced than those of $\mathrm{CHBr}_{3}$ and $\mathrm{CH}_{2} \mathrm{Br}_{2}$. Since the latter compounds are the dominant bromocarbons in oceanic waters, the metabolic pathway within phytoplankton seems to preferentially involve $\mathrm{CHBr}_{3}$ and $\mathrm{CH}_{2} \mathrm{Br}_{2}$. Nucleophilic substitution of $\mathrm{CHBr}_{3}$ by chlorine ions could partly explain $\mathrm{CHBr}_{2} \mathrm{Cl}$ and $\mathrm{CHBrCl}_{2}$ production (Class and Ballschmiter, 1988). However, halogen exchange reactions are extremely slow with an estimated $\mathrm{CHBr}_{3}$ halflife time of 1.3 to 18.5 years (see references in Carpenter and Liss, 2000). Hence a significant time delay would be expected between elevated $\mathrm{CHBr}_{3}$ concentrations and chemical $\mathrm{CHBr}_{2} \mathrm{Cl}$ and $\mathrm{CHBrCl}_{2}$ production. The decay of organic matter, including the involvement of heterotrophic bacteria, could represent an additional source for these bromocarbons. However, since AOU was not positively correlated 

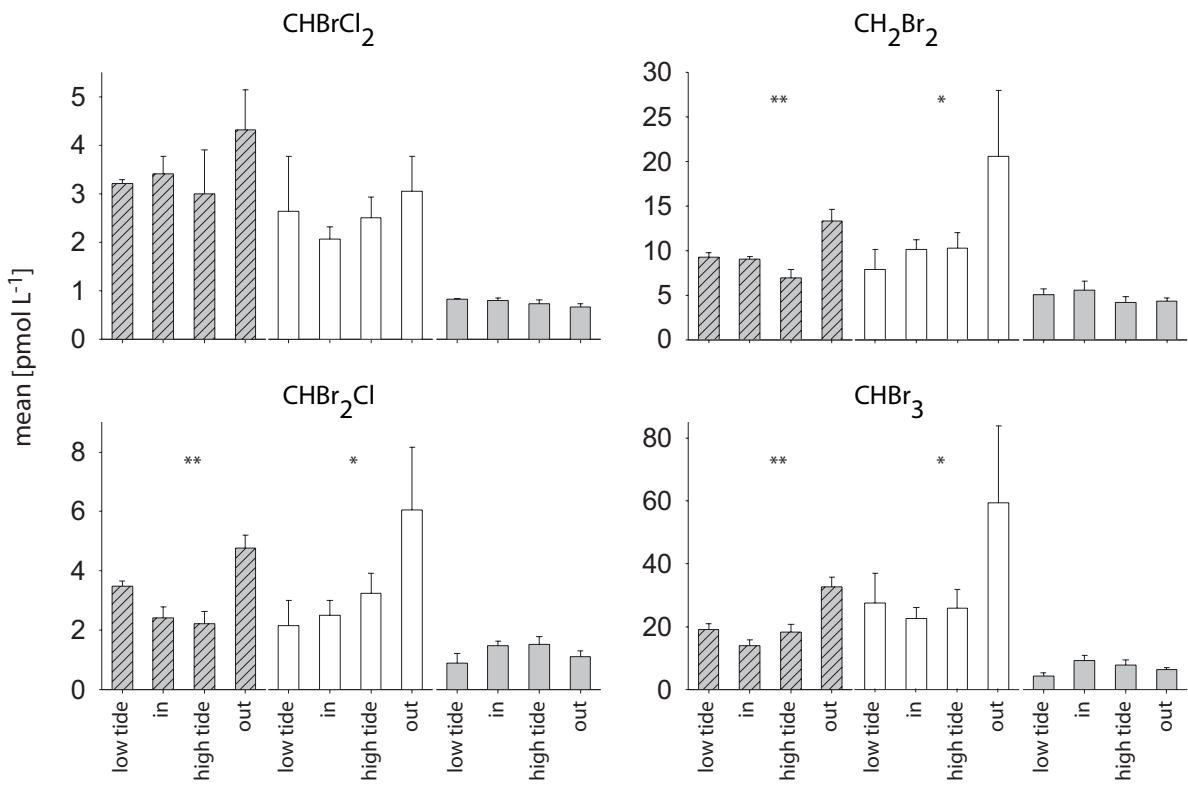

Fig. 8. Bromocarbon concentrations against tide in the upper water layers. Data are clustered into three water masses: recently upwelled waters (gray shaded), aged upwelled waters (white) and open ocean waters (gray). Mean values of four tidal steps (low tide, incoming mid tide, high tide, outgoing mid tide). Confidence levels: * significant at $90 \%$. ** significant at $95 \%$.

to bromocarbons in any water mass in our study, the decay of organic matter was presumably not an important bromocarbon source at this time of the year.

\subsection{Evidence for a near shore source}

According to the results of the correlation analysis, phytoplankton dominated the production of brominated compounds in the open ocean. In the recently and aged upwelled waters, however, correlations to marker pigments were less pronounced. Beside different species compositions, an additionaly non-phytoplanktonic source could explain the lack of correlations in the upwelled waters. Such non-phytoplanktonic sources could be free floating macroalgae (Moore and Tokarczyk, 1993), decay of organic matter (Klick, 1992), or the transport of halocarbon enriched coastal waters to the open ocean (Carpenter and Liss, 2000; Chuck et al., 2005). Regarding the coastal waters, the sources are related to macroalgae (e.g. Nightingale et al., 1995) and, to a lesser extent, to anthropogenic sources such as discharge from power plants (Quack and Wallace, 2003). During our cruise, the fresh water discharge by rivers was relatively low (Fig. 1b), especially during summer with low average precipitation. As shown in Fig. 1b, sea surface salinity values along the coast differed by only 0.5 PSU from oceanic samples. River plume boundaries are characterized by salinity values more than 1 PSU lower than surrounding water masses (Abril and Borges, 2004). Consequently, the influence of river plumes (Minho, Douro) (i.e. anthropogenic sources) seemed negligible during our summer cruise, which suggested a different near shore mechanism.
The temporal dynamics of bromocarbon concentrations (Fig. 4) can be significantly influenced by coastal sources. We analysed the influence of daytime and tide, which are known to have effects on coastal halocarbon concentrations (e.g. Carpenter et al., 1999). Analyses of variances (ANOVA) were computed for all samples taken from the biologically active upper layers. For the ANOVA, the data set was arranged according to the three water masses and additionally by time and tide, respectively. The factors time and tide were necessarily analysed separately, since the tidal cycles are synchronized to lunar month (27.3 day) intervals and hence daily tidal cycles shift forward in time. The tidal day is characterized by two high and two low water periods (semi-diurnal tide) along the Iberian coast. The temporal sequence of low and high tides are synchronized with the tidal amplitude: during the cruise, two spring tides with a maximum tidal amplitude occurred on 14 and 31 August (Fig. 4). At these times, tide was low in the morning and afternoon. The low tide then shifted constantly until the next neap tides (lowest tidal amplitude on 22 August and 5 September, respectively). At neap tide, the low tide occurred around noon and midnight. Thus possible tidal and temporal effects on halocarbon concentration could complement or oppose one another on different dates.

The temporal division of the dataset followed the natural daily cycle and was clustered into four groups: night, morning, day and evening. Night and day were defined as two hours before sunrise and sunset, respectively. Morning and evening were defined as intermediates between day and night. During the campaign the day period lasted about 
$6.5 \mathrm{~h}$, the night period about $9.5 \mathrm{~h}$ and morning and evening exactly $4 \mathrm{~h}$ in each case. The ANOVA revealed that day time had significant effects on $\mathrm{CH}_{2} \mathrm{Br}_{2}, \mathrm{CHBr}_{2} \mathrm{Cl}$ and $\mathrm{CHBr}_{3}$ concentration in recently upwelled water masses (Fig. 7). Bromocarbons were significantly higher in the evening, as compared to the rest of the day (factor 1.5 to 1.8 at p-values below 0.055). In aged upwelled waters, variances of bromocarbon concentrations were statistically not significant. In open ocean waters, diurnal variations of $\mathrm{CH}_{2} \mathrm{Br}_{2}, \mathrm{CHBr}_{2} \mathrm{Cl}$ and $\mathrm{CHBrCl}_{2}$ were also low and only $\mathrm{CHBr}_{3}$ showed remarkably higher concentrations during night time (factor 2 at $p=0.05$ ). Diurnal production of halocarbon concentrations are controlled by elevated photon flux densities at midday, which stimulate the rate of photosynthesis and consequently enzymatic halocarbon production (Goodwin et al., 1997b). Such effects have been shown for macroalgae (Ekdahl et al., 1998; Nightingale et al., 1995; Laturnus et al., 1998) and microalgae (Abrahamsson et al., 2004). The higher midday concentrations in these studies are in contrast to our findings, where $\mathrm{CH}_{2} \mathrm{Br}_{2}, \mathrm{CHBr}_{2} \mathrm{Cl}$ and $\mathrm{CHBr}_{3}$ concentrations were elevated in the evening.

In order to investigate the factor tide and its potential impact on halocarbon concentration, the data set was clustered into four groups: low tide, incoming tide, high tide and outgoing tide. The tidal clustering was achieved by coordinating sampling time with a tide table, provided by SHOM (Service Hydrographique et Océanographique de la Marine, Brest, France) for different locations along the Iberian coast. Hence the sampling time at sea reflected the tidal period at the coast. The influence of tide was evident for $\mathrm{CH}_{2} \mathrm{Br}_{2}, \mathrm{CHBr}_{2} \mathrm{Cl}$ and $\mathrm{CHBr}_{3}$ in recently upwelled waters, visible in aged upwelled waters, and not significant in the open ocean (Fig. 8). In recently upwelled waters, concentrations of $\mathrm{CH}_{2} \mathrm{Br}_{2}, \mathrm{CHBr}_{2} \mathrm{Cl}$ and $\mathrm{CHBr}_{3}$ were significantly elevated at the outgoing tide near shore (factor 1.6-1.9 at $p<0.01$ ). In aged upwelled waters, tidal correlations of these three compounds were higher with maxima at outgoing tide (2.2 to 2.3 -fold elevated) but with a weaker significance level $(0.05>p>0.1)$. Variances of $\mathrm{CHBrCl}_{2}$ were statistically not significant in all water masses.

Our finding of elevated bromocarbon concentrations at outgoing tide along the coast are consistent with other studies (Jones et al., 2009; Peters et al., 2005; Nightingale et al., 1995; Carpenter et al., 2000). In these studies, coastal air and water concentrations increased with lower water levels and showed minima at higher water levels. The tidal and temporal offsets between our observations and the previous studies reflect a possible coastal source associated with lateral transport of halocarbon enriched waters towards the upwelling region. Tidal currents might elevate halocarbon concentrations at outgoing tide. However, these tidal residual currents are expected to be very low and variable several kilometres from the coast (Marta-Almeida and Dubert, 2006) where our sampling sites were located and therefore cannot explain the entire transport of water mass. Hence, we propose a mechanism, which shows that intertidal macroalgae beds can be related to the elevated bromocarbons in the Iberian upwelling. The incoming tide mixes and homogenizes near-shore waters, increasing the overall concentrations of freshly produced halocarbons. Then, the low tide associated with the westward surface upwelling currents (Rossi et al., 2010) leads to offshore transport of these bromocarbon enriched coastal waters. This would induce elevated bromocarbon concentrations far from the coastline several hours after the low tide. The surface offshore velocities ranged roughly from 0.1 to $0.2 \mathrm{~m} \mathrm{~s}^{-1}$ for the first leg (strong winds favourable for upwelling), giving a transport of 10 to $20 \mathrm{~km}$ (from the coast to the sampling sites) within $24 \mathrm{~h}$. Hence high measured concentrations in the coastal upwelling might be related to intertidal production during the previous tidal cycle, followed by offshore transport.

Despite the general advection processes, bromocarbon distributions were very patchy along the Iberian coast (Fig. 3). This could be related to the variability of either the source strength or the water transport towards the upwelling. Different species composition and macroalgae cover could be responsible for differences in coastal sources. However, data on macroalgae cover along the coast are scarce.

It can be assumed that the source strength fluctuates along the Iberian coast, which may explain particularly elevated bromocarbon concentrations between $41^{\circ} \mathrm{N}$ and $42^{\circ} \mathrm{N}$ and around $39.5^{\circ} \mathrm{N}$. Further, the complex shelf topography of the Iberian upwelling system creates small scale instabilities which may interfere with transport caused by tidal mixing and upwelling currents. Along the north-south transect, cyclonic eddies alternate with anticyclonic eddies (Rossi et al., 2011). The small scale instabilities created highly variable patterns of cross-shore and along shore currents with effects on biological, physical and geochemical variables. In addition, areas of highest bromocarbon concentrations coincided with areas of highest SST anomalies, computed by Relvas et al. (2007) for the period between 2001-2005. High SST anomalies determine elevated upwelling and consequently nutrient supply. We postulate that this elevated nutrient supply might have positive implications on coastal macroalgae growth rates and consequently halocarbon production.

\section{Conclusions}

Our investigation of the Iberian peninsula upwelling revealed that $\mathrm{CH}_{2} \mathrm{Br}_{2}, \mathrm{CHBrCl}_{2}, \mathrm{CHBr}_{2} \mathrm{Cl}$ and $\mathrm{CHBr}_{3}$ concentrations were elevated in the upwelling compared to the open ocean. Complex interactions of along-shore and cross-shore currents and differences in source strength likely caused the strong patchiness of bromocarbon distribution in the studied area. Contrary to the assumption of a strong phytoplanktonrelated source within the upwelling, measured bromocarbon concentrations were low compared to macroalgae influenced coastal areas or diatom dominated arctic waters. Although 
the Iberian upwelling is thus not a pronounced "hot spot" for halocarbon formation, a phytoplankton source in the studied area was evident. In the upwelling along the coast, an additional coastal source further increased the bromocarbon concentration. This coastal source was correlated to the diurnal and tidal cycles, a typical feature for halocarbon production in intertidal macroalgae beds.

We suggest that further studies should be conducted on the inner shelf between the shore line and the upwelling in order to localize important sources and assess the westward transport of halocarbon-enriched coastal waters. This type of study would complement our investigation of the middle and outer shelf of the Iberian upwelling and would provide a comprehensive understanding of halocarbon sources in this highly heterogeneous system.

Acknowledgements. The authors thank Joelle Tassel (SHOM) for pigment measurements, Danièle Thouron (LEGOS) for nutrient analysis as well as Eric Macé (SBR) and Thierry Cariou (SBR) for technical assistance. We thank Ian Probert for his comments on a previous version of the manuscript. We are grateful to the SHOM for making possible our participation to the cruise. The excellent co-operation of captain and the crew of R/V Pourquoi pas is gratefully acknowledged. S.R. was supported by a European Marie Curie PhD grant.

Edited by: K. Suzuki

\section{References}

Abrahamsson, K., Loren, A., Wulff, A., and Wangberg, S. A.: Air-sea exchange of halocarbons: The influence of diurnal and regional variations and distribution of pigments, Deep-Sea Res. Part Ii-Topical Studies in Oceanography, 51, 2789-2805, doi:10.1016/j.dsr2.2004.09.005, 2004.

Abril, G. and Borges, A. V.: Carbon dioxide and methane emissions from estuaries, in: Greenhouse gas emissions - fluxes and processes, edited by: Tremblay, A., Varfalvy, L., Roehm, C., and Garneau, M., Environmental science, Springer, Berlin Heidelberg, 187-207, 2004.

Bravo-Linares, C. M. and Mudge, S. M.: Temporal trends and identification of the sources of volatile organic compounds in coastal seawater, J. Environm. Monitoring, 11, 628-641, doi:10.1039/B814260m, 2009.

Bulsiewicz, K., Rose, H., Klatt, O., Putzka, A., and Roether, W.: A capillary-column chromatographic system for efficient chlorofluorocarbon measurement in ocean waters, J. Geophys. Res.Oceans, 103, 15959-15970, 1998.

Butler, J. H., King, D. B., Lobert, J. M., Montzka, S. A., YvonLewis, S. A., Hall, B. D., Warwick, N. J., Mondeel, D. J., Aydin, M., and Elkins, J. W.: Oceanic distributions and emissions of short-lived halocarbons, Global Biogeochem. Cycles, 21, Gb1023, doi:10.1029/2006gb002732, 2007.

Carpenter, L. J. and Liss, P. S.: On temperate sources of bromoform and other reactive organic bromine gases, J. Geophys. Res.Atmos., 105, 20539-20547, 2000.

Carpenter, L. J., Sturges, W. T., Penkett, S. A., Liss, P. S., Alicke, B., Hebestreit, K., and Platt, U.: Short-lived alkyl iodides and bromides at mace head, ireland: Links to biogenic sources and halogen oxide production, J. Geophys. Res.-Atmos., 104, 16791689, 1999.

Carpenter, L. J., Malin, G., Liss, P. S., and Kupper, F. C.: Novel biogenic iodine-containing trihalomethanes and other short-lived halocarbons in the coastal east atlantic, Global Biogeochem. Cycles, 14, 1191-1204, 2000.

Carpenter, L. J., Wevill, D. J., O’Doherty, S., Spain, G., and Simmonds, P. G.: Atmospheric bromoform at Mace Head, Ireland: seasonality and evidence for a peatland source, Atmos. Chem. Phys., 5, 2927-2934, doi:10.5194/acp-5-2927-2005, 2005.

Carpenter, L. J., Wevill, D. J., Palmer, C. J., and Michels, J.: Depth profiles of volatile iodine and bromine-containing halocarbons in coastal antarctic waters, Marine Chemistry, 103, 227-236, doi:10.1016/j.marchem.2006.08.003, 2007.

Carpenter, L. J., Jones, C. E., Dunk, R. M., Hornsby, K. E., and Woeltjen, J.: Air-sea fluxes of biogenic bromine from the tropical and North Atlantic Ocean, Atmos. Chem. Phys., 9, 1805-1816, doi:10.5194/acp-9-1805-2009, 2009.

Chuck, A. L., Turner, S. M., and Liss, P. S.: Oceanic distributions and air-sea fluxes of biogenic halocarbons in the open ocean, J. Geophys. Res.-Oceans, 110, C10022, doi:10.1029/2004jc002741, 2005.

Class, T. H. and Ballschmiter, K.: Chemistry of organic traces in air .8. Sources and distribution of bromochloromethanes and bromochloromethanes in marine air and surfacewater of the atlanticocean, J. Atmos. Chem., 6, 35-46, 1988.

Coelho, H. S., Neves, R. J. J., White, M., Leitao, P. C., and Santos, A. J.: A model for ocean circulation on the iberian coast, J. Marine Syst., 32, 153-179, Pii S0924-7963(02)00032-5, 2002.

Ekdahl, A., Pedersen, M., and Abrahamsson, K.: A study of the diurnal variation of biogenic volatile halocarbons, Marine Chemistry, 63, 1-8, 1998.

Goodwin, K. D., Lidstrom, M. E., and Oremland, R. S.: Marine bacterial degradation of brominated methanes, Environ. Sci. Technol., 31, 3188-3192, 1997a.

Goodwin, K. D., North, W. J., and Lidstrom, M. E.: Production of bromoform and dibromomethane by giant kelp: Factors affecting release and comparison to anthropogenic bromine sources, Limnol. Oceanogr., 42, 1725-1734, 1997b.

Gruber, N. and Sarmiento, J. L.: Global patterns of marine nitrogen fixation and denitrification, Global Biogeochem. Cycles, 11, 235-266, 1997.

Hill, V. L. and Manley, S. L.: Release of reactive bromine and iodine from diatoms and its possible role in halogen transfer in polar and tropical oceans, Limnol. Oceanogr., 54, 812-822, 2009.

Hughes, C., Chuck, A. L., Rossetti, H., Mann, P. J., Turner, S. M., Clarke, A., Chance, R., and Liss, P. S.: Seasonal cycle of seawater bromoform and dibromomethane concentrations in a coastal bay on the western antarctic peninsula, Global Biogeochem. Cycles, 23, Gb2024, doi:10.1029/2008gb003268, 2009.

Jones, C. E., Hornsby, K. E., Dunk, R. M., Leigh, R. J., and Carpenter, L. J.: Coastal measurements of short-lived reactive iodocarbons and bromocarbons at Roscoff, Brittany during the RHaMBLe campaign, Atmos. Chem. Phys., 9, 8757-8769, doi:10.5194/acp-9-8757-2009, 2009.

Klick, S.: Seasonal-variations of biogenic and anthropogenic halocarbons in seawater from a coastal site, Limnol. Oceanogr., 37, 1579-1585, 1992. 
Klick, S. and Abrahamsson, K.: Biogenic volatile iodated hydrocarbons in the ocean, J. Geophys. Res.-Oceans, 97, 12683-12687, 1992.

Krysell, M.: Bromoform in the nansen basin in the arctic-ocean, Marine Chemistry, 33, 187-197, 1991.

Laturnus, F., Wiencke, C., and Adams, F. C.: Influence of light conditions on the release of volatile halocarbons by antarctic macroalgae, Marine Environ. Res., 45, 285-294, 1998.

Law, C. S. and Sturges, W. T.: Halogenated very short-lived substances, in: World meteorological organization global ozone research and monitoring project, report no. 50, 2006.

Leblanc, C., Colin, C., Cosse, A., Delage, L., La Barre, S., Morin, P., Fievet, B., Voiseux, C., Ambroise, Y., Verhaeghe, E., Amouroux, D., Donard, O., Tessier, E., and Potin, P.: Iodine transfers in the coastal marine environment: The key role of brown algae and of their vanadium-dependent haloperoxidases, Biochimie, 88, 1773-1785, doi:10.1016/j.biochi.2006.09.001, 2006.

Manley, S. L., Goodwin, K., and North, W. J.: Laboratory production of bromoform, methylene bromide, and methyl-iodide by macroalgae and distribution in nearshore southern california waters, Limnol. Oceanogr., 37, 1652-1659, 1992.

Marta-Almeida, M. and Dubert, J.: The structure of tides in the western iberian region, Cont. Shelf Res., 26, 385-400, doi:10.1016/j.csr.2005.11.011, 2006.

Moore, R. M. and Tokarczyk, R.: Volatile biogenic halocarbons in the northwest atlantic, Global Biogeochem. Cycles, 7, 195-210, 1993.

Moore, R. M., Webb, M., Tokarczyk, R., and Wever, R.: Bromoperoxidase and iodoperoxidase enzymes and production of halogenated methanes in marine diatom cultures, J. Geophys. Res.Oceans, 101, 20899-20908, 1996.

Nightingale, P. D., Malin, G., and Liss, P. S.: Production of chloroform and other low-molecular-weight halocarbons by some species of macroalgae, Limnol. Oceanogr., 40, 680-689, 1995.

Pedersen, M., Collen, J., Abrahamsson, K., and Ekdahl, A.: Production of halocarbons from seaweeds: An oxidative stress reaction?, Scientia Marina, 60, 257-263, 1996.

Perez, F. F., Castro, C. G., Alvarez-Salgado, X. A., and Rios, A. F.: Coupling between the iberian basin - scale circulation and the portugal boundary current system: A chemical study, DeepSea Res. Part I-Oceanographic Research Papers, 48, 1519-1533, 2001.

Peters, C., Pechtl, S., Stutz, J., Hebestreit, K., Hönninger, G., Heumann, K. G., Schwarz, A., Winterlik, J., and Platt, U.: Reactive and organic halogen species in three different European coastal environments, Atmos. Chem. Phys., 5, 3357-3375, doi:10.5194/acp-5-3357-2005, 2005.

Pruvost, J., Connan, O., Marty, Y., and Le Corre, P.: A sampling device for collection and analysis of volatile halocarbons in coastal and oceanic waters, Analyst, 124, 1389-1394, 1999.

Quack, B. and Wallace, D. W. R.: Air-sea flux of bromoform: Controls, rates, and implications, Global Biogeochem. Cycles, 17, 1023, doi:10.1029/2002gb001890, 2003.
Quack, B., Atlas, E., Petrick, G., Stroud, V., Schauffler, S., and Wallace, D. W. R.: Oceanic bromoform sources for the tropical atmosphere, Geophys. Res. Lett., 31, L23s05, doi:10.1029/2004g1020597, 2004.

Quack, B., Peeken, I., Petrick, G., and Nachtigall, K.: Oceanic distribution and sources of bromoform and dibromomethane in the mauritanian upwelling, J. Geophys. Res.-Oceans, 112, C10006, doi:10.1029/2006jc003803, 2007.

Read, K. A., Mahajan, A. S., Carpenter, L. J., Evans, M. J., Faria, B. V. E., Heard, D. E., Hopkins, J. R., Lee, J. D., Moller, S. J., Lewis, A. C., Mendes, L., McQuaid, J. B., Oetjen, H., SaizLopez, A., Pilling, M. J., and Plane, J. M. C.: Extensive halogenmediated ozone destruction over the tropical atlantic ocean, Nature, 453, 1232-1235, doi:10.1038/Nature07035, 2008.

Relvas, P., Barton, E. D., Dubert, J., Oliveira, P. B., Peliz, A., da Silva, J. C. B., and Santos, A. M. P.: Physical oceanography of the western iberia ecosystem: Latest views and challenges, Prog. Oceanogr., 74, 149-173, doi:10.1016/j.pocean.2007.04.021, 2007.

Rossi, V., Morel, Y., and Garcon, V.: Effect of the wind on the shelf dynamics: Formation of a secondary upwelling along the continental margin, Ocean Model, 31, 51-79, doi:10.1016/j.ocemod.2009.10.002, 2010.

Rossi, V., Garçon, V., Tassel, J., Romagnan, J. B., Stemmann, L., Jourdin, F., Morin, P., and Morel, Y.: A mesoscale survey of the northern and central Iberian Peninsula Upwelling System: spatial variability and bio-physical interactions, Prog. Oceanogr., in review, 2011.

Salawitch, R. J., Weisenstein, D. K., Kovalenko, L. J., Sioris, C. E., Wennberg, P. O., Chance, K., Ko, M. K. W., and McLinden, C. A.: Sensitivity of ozone to bromine in the lower stratosphere, Geophys. Res. Lett., 32, L05811, doi:10.1029/2004g1021504, 2005.

Smyth, T. J., Miller, P. I., Groom, S. B., and Lavender, S. J.: Remote sensing of sea surface temperature and chlorophyll during lagrangian experiments at the iberian margin, Prog. Oceanogr., 51, 269-281, 2001.

Sturges, W. T., Cota, G. F., and Buckley, P. T.: Bromoform emission from arctic ice algae, Nature, 358, 660-662, 1992.

Tokarczyk, R. and Moore, R. M.: Production of volatile organohalogens by phytoplankton cultures, Geophys. Res. Lett., 21, 285-288, 1994.

von Glasow, R., von Kuhlmann, R., Lawrence, M. G., Platt, U., and Crutzen, P. J.: Impact of reactive bromine chemistry in the troposphere, Atmos. Chem. Phys., 4, 2481-2497, doi:10.5194/acp4-2481-2004, 2004.

Wright, S. W., Jeffrey, S. W., Mantoura, R. F. C., Llewellyn, C. A., Bjornland, T., Repeta, D., and Welschmeyer, N.: Improved hplc method for the analysis of chlorophylls and carotenoids from marine-phytoplankton, Marine Ecology-Progress Series, 77, 183-196, 1991. 